\title{
Market Structure and Bank Performance: Empirical Evidence of Islamic Banking in Indonesia
}

\author{
Etty Nurwati ${ }^{1}$, Noer Azam Achsani ${ }^{1}$, Didin Hafidhuddin ${ }^{1} \&$ Nunung Nuryartono ${ }^{1}$ \\ ${ }^{1}$ Graduate School of Management and Business, Bogor Agricultural University, Indonesia \\ Correspondence: Etty Nurwati, Graduate School of Management and Business, Bogor Agricultural University, \\ Indonesia. Tel: 62-21-745-2938. E-mail: etty.nurwati@gmail.com
}

Received: January 13, 2014 Accepted: March 5, 2014 Online Published: April 29, 2014

doi:10.5539/ass.v10n10p105 URL: http://dx.doi.org/10.5539/ass.v10n10p105

\begin{abstract}
The relationship between market structure and bank performance has been studied extensively in various countries, some of those using a structure-conduct-performance (SCP) approach. Previous studies showed that market structure was found to be one of the main factors of bank performance. Most of the study primarily focused on conventional banking industry, while the study of relationship between market structure and performance of the Islamic Banks in Indonesia is very limited.

The purpose of this study was to examine the relationship between market structure and performance of the Islamic Banks in Indonesia, for a period of 12 years from year 1999 to 2011, using regression panel data analysis The result of this study indicate the significant relationship between market concentration (HHI) with Return of Equity (ROE) of Islamic Banks in Indonesia. Number of Sharia Business Unit has a positive effect on Return on Assets (ROA) and ROE of Islamic Banks in Indonesia. Meanwhile the firm ownership did not show any significant relationship to ROE and ROA of Islamic Banks in Indonesia.
\end{abstract}

Keyword: market structure, market concentration, Islamic Banks in Indonesia, bank performance

\section{Introduction}

Islamic Banking system in Indonesia began in 1992 with the issuance of Regulation No. 7/1992 which enables bank to run its Islamic Banking operations with profit sharing system. In 1992 the first Islamic Bank in Indonesia, Bank Muamalat Indonesia (BMI), was established. After the launch of the Dual Banking System through Regulation No.10/.1998 as amendment of Regulation No 7/1992 concerning Banking, Indonesian Islamic Banking started to rise, beginning with the establishment of Bank Mandiri Sharia in 1999 which is its own entity. Besides Islamic Bank (IB), Sharia Islamic Banking Unit (SBU), which is part of the parent entity, continued to grow.

The presence of Islamic Banking in Indonesia became one of the promising alternative financing concepts. The concept of Islamic Banking was still relatively new to the people of Indonesia, including the Muslim community itself. However, with the banking regulations that encourage the development of Islamic Banking and the growth of Islamic Banking performance, those become the main attraction for conventional banks and investors to open Islamic Banks, Sharia Business Units and Islamic Rural Banks. As of the end of 2011, the number of Islamic Banks in Indonesia is 11 banks and SBUs are 24 units. Nine (9) of the Islamic Banks in Indonesia are subsidiary of a conventional bank, and those can be classified into two groups: 1) Government (State-Owned Commercial Bank and Regional Development Banks) and 2) Private Owned Bank.

Based on the statistical data of Indonesian Central Bank, the Indonesian Islamic Banking assets grew by $5.23 \%$ over the last ten years. This growth was higher than the growth in the banking industry as a whole in the same time frame. The Islamic Banking market share growed more than $0.25 \%$ in 2001 to $4.7 \%$ in 2011, but this market share was much lower than the target of 5\% market share in 2008. To increase the market share, the government has made some efforts to the growth of Islamic Banks, either by opening Islamic Banking subsidiaries of the parent conventional bank, conversing from conventional banks into Islamic Banks, encouraging SBU development, or by other policies. The existence of this policy can certainly affect the structure of the Islamic Banking industry, market concentration, the level of competition and may further affect its performance.

By understanding the relationship between market structure and performance of the Islamic Bank in Indonesia, 
will be useful for companies and regulators, in particular to identify the key determinants of the performance of Islamic Bank in Indonesia. This paper examines the effect of market concentration and other factors of market structures on the performance of Islamic Bank in Indonesia.

The paper is organized as follows: Chapter 1 Introduction, Chapter 2 Literatur reviews of previous research related to this study. Chapter 3 describes the data and methodology of the study, Chapter 4 is the result of research and discussion, and Chapter 5 contains a summary of the research results and policy implications.

\section{Literature Review}

\subsection{Market Structure}

In most studies, market structure was found to be one of the main factors of bank performance. Profitability of banks found to be positively related to the level of market concentration. It means that profitability will be increased by increasing of market concentration and combined price, and smaller number of competitors. This shows that concentration can have adverse effects on the environment of industry competition. Several studies found that banks with a larger market share and have a strong market forces can obtain supernormal profits, which would hinder competition and may affect the sound of small banks. Conversely, there are other studies found that the relationship between bank performance and concentration or market power is false. These findings indicated that the relative performance of each bank and the profitability of the industry is more dependent on bank production efficiency, in addition to other operational conditions and macro-economic factors.

The relationship between market structure and bank performance has been studied extensively in various countries, some of those using a structure-conduct-performance (SCP) hypothesis. Structure-ConductPerformance (SCP) can be defined as the relationship between market structure, conduct and performance of the corporate enterprise. The structure-conduct-performance (SCP) model has been derived from the economic concepts of market structure in the 1940s and 1950s. Bain (1950) were the first to develop this model by finding a statistically significant relationship between profitability and concentration of manufacturing industries in the United States. The new approach has been developed, by Demsetz (1973), to explain the relationship between market structure and performance. This study shows that the positive relationship between concentration and profits may reflect differential efficiency of the largest and small companies, not collusion. Thus, a positive relationship between concentration and profits caused by the increase in market share by the company is more efficient, leading in turn to an increase in concentration.

Most studies conclude that if the market structure consists of several companies, the implementation of the company is more likely to include efforts to establish excessive prices and make suboptimal output, combined with the estimated revenue maximization (Heggested, 1977; Heggested \& Mingo, 1977). When bank regulation was developed, the traditional SCP paradigm has been the driving force behind the industry's antitrust enforcement. Since then, many empirical studies have been conducted on SCP in the banking industry is done by reflecting the previous industry studies. That study focused on the banking industry indicators, such as prices, costs and profitability, as a barometer to serve the community. Evanoff and Fortier (1988), Smirlock (1985) and Gilbert (1984), who have studied the relationship between the structures of the banking market, stated that bank profitability is mainly due to the company's efficiency. McLeay and Molyneux (1989), showed significant evidence that there was a positive relationship between concentration and bank performance.

According to microeconomic theory, market structure influenced the behavior of their respective companies. The length of the structure, in the context of SCP model, referring to the number of banks that serve a particular market and the barriers to entry into the market. Market structure responds to internal variables, such as competition and regulation, as well as external variables, such as changes in technology, economic and population situation. Lewis and Davis (1987) argue that in most developed countries, banks are highly concentrated. In other words, the SCP model shows that market concentration lower the cost of collusion between the banks and end up in suboptimal, which is higher than normal, the advantages for all market participants.

Smirlock (1985) illustrates that there is no relationship between concentration and profitability, but the Bank's market share and profitability of banks. The hypothesis states that the market concentration is not a random event, but the result of the company superior efficiency gain substantial market share. In this case, market share and profitability are correlated but there will be no relationship between market concentration and profitability. These findings do not support the idea that the market concentration in banking generates monopoly profits obtained, and showed that the effect of the concentration reported in previous studies is spurious and probably due to the relationship between profitability and market share variable is eliminated. 
Molyneux and Forbes (1995) explains that the market structure and performance in 18 European countries for the four year period 1986-89 were measured to test the two hypotheses SCP and ES, using the collected annual data. He showed that if the SCP paradigm found clearly in the European market, this would mean that the antitrust or regulatory policies should be aimed at changing market structures in order to improve the quality of the rivalry or Bank Performance. If the hypothesis of efficiency is found, then the increase in the concentration of the banking market should not be limited by antitrust or regulatory action. In this study, to measure the performance of the bank used Return on Assets (ROA), and the independent variables include certain markets and company-specific variables. Ten firms concentration ratio (CR10) is used as a measure of market structure and measure market share for the capture efficiency of the company. A number of control variables included to account for other risks, costs, size and ownership characteristics. The result presents SCP support to the traditional approach. In short, they showed that the concentration in European banking markets lower the cost of collusion between firms.

Chirwa (2003) examined the relationship between market structure and profitability of commercial banks in Malawi using time series data between 1970 and 1994. Competition in the primary market for commercial banks increased due to an increase in the number of financial institutions and commercial banks. Bhatti (2010) conducted a study on the relationship of market structure and bank performance in Pakistan, by using regression analysis model; the results show that there is a positive effect of the ratio between the concentrations of performance.

Ajlouni (2010) examined the market structure based on empirical studies from 1960 to 1980. The result provides evidence of how market structure affects the performance of the banking organization. Empirical studies are categorized into two groups. The first group to evaluate the relationship between market structure and performance of the company's banks, which found that 'one third' of the studies, reported a positive relationship entirely. While in the second group concentrates on efficient market structures that are conductive to competitive pricing of banking services. To measure performance, the majority of approaches using Return on Assets ratio (ROA), profit sharing and fee of the total financing (Net Interest Income-NII), Return on enquiry (ROE), Interest Rate on Loan (Funding) and profit sharing paid on deposits.

\subsection{Firm Ownership}

Several studies have been conducted to examine the relationship between the performances of the Bank's ownership structure. Short (1979); showed that there is a negative relationship between government ownership of the Bank's profitability. Bourke (1989) also showed a negative coefficient in the profit equation, using a dummy variable of government ownership and return on assets (ROA) and Return on Capital (ROC) as the dependent variable. Hadad et al. (2003) conducted a study of the relationship of ownership structure and bank performance in Indonesia. He conducted a study on how performance of a bank will be affected by who is the owner of the bank, by using empirical data of 131 banks. Among six performance measurements that he used, there were Return on Assets (ROA) and Operating Expenses compared to Operating Income (OER). Hadad et al. (2003) concluded that the bank performance depend on (1) the achievement of the performance of an organization depends on the performance of management, (2) management performance can be affected by the intervention of the owner, (3) management cannot act solely for the benefit of the owner, although the goal to maximize profits, and (4) owners can do the management of organizational intervention. It can also be concluded that bank performance is not entirely influenced by the ownership structure.

\section{Data and Methodology}

\subsection{Data}

The research was conducted by taking secondary data from quarterly financial reports and annual reports of 11 Islamic Bank in Indonesia, Indonesian Central Bank statistics, for the period 1999-2011. To determine the effect of bank ownership, in this study, the Islamic Banks in Indonesia are grouped into two groups: 1) Islamic Bank owned by government and 2) Islamic Bank owned by private. There are four government-owned Islamic banks, namely 1) Bank Mandiri Sharia, 2) BNI Sharia, 3) BRI Sharia and 4) BJB Sharia. The privately-owned banks include 1) Bank Muamalat Indonesia, 2) Bank Mega Sharia 3) Bukopin Sharia, 4) BCA Sharia, 5) Bank PANIN Sharia, 6) Bank Victoria Sharia, and 7) Maybank Sharia.

To analyze the influence of the market structure to bank performance, we used several variables as follows:

1) The number of Islamic Banks (IB), in Indonesia in the period 1999-2011;

2) The number of Sharia Business Unit (SBU) in Indonesia in the period 1999-2011.

3) The concentrations used Hirshmann the Herfindahl Index (HHI), is a measure of company size and industry 
indicators in relation to the amount of competition among them.

4) Size of the company-the total assets (SIZE).

5) Firm ownership type (DOWN)

\subsection{Methodology}

For the initial analysis we used exploratory data analysis by calculating the HHI and CR4 in 2010-2011, to determine the structure of Islamic banking market in general. Then to determine the effect of structural factors on the performance of Islamic Bank industrial we use panel data analysis approach with Stata statistical package. To measure of the concentration ratio of HHI (Herfindahl Hirshmann the Index) is calculated by summing the squared market share of each firm in the industry multiplied by 10,000 , or the formula is as follows:

$$
\mathrm{HHI}=10.000 \Sigma \mathrm{Wi}
$$

Where $W$ is the market share of firm $i$ is in industry.

To analyze the effect of market structure on the performance of the Islamic Bank will use panel data regression model is expressed as follows:

$$
Y_{\text {it }}{ }^{m}=\alpha_{1 \text { it }}+\alpha_{2} \text { it } D_{1}+\beta_{1} X_{i t}{ }^{m}+e_{i t}
$$

Where

$\mathrm{i}=1,2, \ldots, \mathrm{N} ;$ firm; $\mathrm{t}=1,2, \ldots, \mathrm{T}$; time series;

$\mathrm{Y}_{\text {it }}{ }^{\mathrm{m}}=$ Firm Performance:

$Y_{i t}{ }^{l}=$ Return on Asset (ROA),

$Y_{i t}{ }^{2}=$ Return on equity (ROE),

$Y_{i t}{ }^{3}=$ Operating Expenses/Operating Income (OER),

$Y_{i t}{ }^{4}=$ Financing to Deposit Ratio (FDR),

$Y_{i t}{ }^{5}=$ Total Asset (ASSET),

$Y_{i t}{ }^{6}=$ Profit (PROFIT),

$Y_{i t}{ }^{7}=$ Third Party Fund (TPF),

$Y_{i t}{ }^{8}=$ Financing (FIN);

$\mathrm{X}_{\mathrm{it}}{ }^{\mathrm{m}}=$ Structure:

$X_{i t}{ }^{1}=$ Number of Islamic Bank (IIB),

$X_{i t}{ }^{2}=$ Number of Sharia Business Unit (SBU),

$X_{i t}{ }^{3}=$ Bank Size (Total Asset) Islamic Bank, (SIZE),

$X_{i t}{ }^{4}=$ Herfindahl-Hirschman Index of Islamic Bank (HHI);

$\mathbf{D}_{1}=$ Dummy variable (DOWN), to determine the effect of the difference between the ownership type of the government or private company:

$\boldsymbol{D}_{\mathbf{1}}=1$; Private,

$\boldsymbol{D}_{\mathbf{l}}=0$; Government;

$\mathbf{e}_{\mathbf{i t}}=$ Error.

Data panel (or longitudinal data) is the data that have spatial dimensions (individual) and time. In the data panel, the data cross section has a same observable time. If each unit cross section has a number of observation time series are the same then it is called a balanced panel. Conversely, if the number of observations is different for each unit of cross section is called unbalanced panel. Incorporation of cross section and time series in the study of panel data is used to overcome weaknesses and to answer questions that cannot be answered by the pure model cross section and time series (Baltagi, 2005). To estimate the panel data model, in this study we used three approaches: the least squares approach (Pooled Least Square or PLS), Fixed Effect Model (FEM) and Random Effect Model (REM). Those models are distinguished by the presence or absence of a correlation between the error components with independent variables. 


\subsubsection{Pooled Least Square (PLS)}

This approach is a simple way to use a combination of all the data (pooled), so there are $\mathrm{N} \mathrm{x} \mathrm{T}$ observations, where $\mathrm{N}$ denotes the number of cross section units and $\mathrm{T}$ denotes the number of time points used, which is regressed using the Ordinary Least Square (OLS) model.

\subsubsection{Fixed Effect Model (FEM)}

A Fixed Effects Model is a statistical model that represents the observed quantities in terms of explanatory variables that are treated as if the quantities were non-random. The fixed effect assumption is that the individual specific effect is correlated with the independent variables $X_{i t}$ or have patterns that are not random.

\subsubsection{Random Effect Model (REM)}

A random effect(s) model, is a kind of hierarchical linear model. The random effects assumption is that the individual specific effects are uncorrelated with the independent variables $X_{i t}$. or have patterns that are random.

To test this assumption we use the Haussmann Test. The Haussmann test can be directly used to choose between the FEM and REM. To test which model is more appropriate between REM with PLS, we used test statistics Breusch and Pagam Lagrangian Multiplier test (LM) for random effects.

\subsection{Financial Performance Measurement}

To measure the financial performance of the bank, this study uses four financial ratios adopted from Samad (2000), Ismail (2010).

\subsubsection{Profitability Ratios}

Profitability ratios are used to assess a company's ability to generate earnings as compared with expenses and other related expenses that occurred during the specified time period. This study uses the following ratios to measure the profitability of banks.

$$
\text { Return on Assets }(\mathrm{ROA})=\text { profit after tax/total assets }
$$

This ratio shows how banks can convert assets into net income. The higher value of this ratio indicates a higher ability of the company. This ratio provides an indicator to evaluate the efficiency of managerial,

$$
\text { Return on Equity }(\mathrm{ROE})=\text { profit after tax/equity. }
$$

This ratio shows how banks can make a profit with the money shareholders have invested. The higher value of this ratio indicates higher financial performance. Such as ROA, this ratio is also an indicator of managerial efficiency.

\subsubsection{Liquidity Ratios}

The liquidity ratio measures the bank's ability to meet its short term obligations. Generally, a higher value of this ratio indicates that the company has a greater safety margin to cover its current liabilities. Among the various measures of liquidity, this study uses the following ratios.

$$
\text { Financing to Deposit Ratio (FDR) = financing/deposit }
$$

The low value of this ratio indicates that a bank has excess liquidity. This ratio also shows the effectiveness of the mediation function. In the context of conventional banks, this ratio is known as Loan to Deposit Ratio (LDR). In addition to measuring liquidity, this ratio also shows the risks of financing for a company. The high value of this ratio indicates the possibility of bankruptcy.

\subsubsection{Efficiency Ratio}

In this study the ratio used in the ratio of operational efficiency to measure the efficiency of the bank, as follows.

$$
\text { Operational Efficiency Ratio (OER) = Total Operating Expenses/Total Operating Income }
$$

This ratio shows how efficiently a company uses the assets, revenues and minimizes costs. In other words, it shows how well the company can reduce costs and improve productivity.

\section{Results}

This chapter presents the results of research using panel data analysis with PLS, FEM and REM models, using LISREL program. Table 1 presents the results of data model estimation of market structure parameters that have influence on the performance of ROA, ROE, FDR, TPF, and Financing of Islamic Banks. In general, the estimation gave a good result. This can be seen on the statistical value of $\mathrm{F} /$ Wald test resulted from three estimation methods with significance level 1-5 percent. The results suggest that the Islamic banking market 
structure variables used in the model together affect the performance of the Islamic Bank. To choose the most appropriate model, we used the Chow Test for selecting the most suitable model between the PLS and FEM model, used Haussmann test to choose between FEM and REM model, and used LM test to compare between REM the PLS model. In the test results with the FEM model, if there was a collinearity on the dummy variable test results, then the model would not be used, although the results of the F test and the Chow Test significant.

Table 1. Estimation results of relationship between market structure and Islamic Banks performance variables

\begin{tabular}{|c|c|c|c|c|c|c|c|c|}
\hline \multirow[b]{2}{*}{ No } & \multirow{2}{*}{$\begin{array}{l}\text { Market } \\
\text { Structure } \\
\text { variables }\end{array}$} & \multicolumn{7}{|c|}{ Variable of Islamic Bank Performance* } \\
\hline & & $\mathrm{ROA}^{3)}$ & $\mathrm{ROE}^{1)}$ & $\mathrm{OEOI}^{3)}$ & $\mathrm{FDR}^{3)}$ & PROFIT $^{1)}$ & $\mathrm{TPF}^{2)}$ & $\mathrm{FIN}^{1)}$ \\
\hline 1 & IB & 0.000 & 0.011 & 0.027 & 0.011 & $-1898.08^{b)}$ & $-24373.04^{\mathrm{c})}$ & $-71223.05^{\mathrm{c})}$ \\
\hline 2 & SBU & $0.001^{\mathrm{a})}$ & $0.030^{\mathrm{c})}$ & $-0.010^{\mathrm{b})}$ & -0.005 & $520.30^{\mathrm{b})}$ & $-4546.64^{\mathrm{c}}$ & $15699.33^{\mathrm{c})}$ \\
\hline 3 & SIZE & $-4.50 e-10$ & $-4.17 e-09$ & $-1.29 \mathrm{e}-08$ & $5.53 \mathrm{e}-09$ & $0.009^{\mathrm{c})}$ & $0.089^{\mathrm{c})}$ & $0.7743^{\mathrm{c})}$ \\
\hline 4 & HHI & 0.075 & $1.793^{\mathrm{a})}$ & -0.090 & $3.015^{\mathrm{c})}$ & 25674.33 & 229510.4 & $1192177^{\mathrm{c})}$ \\
\hline 5 & DOWN & -0.005 & -0.154 & $0.481^{\text {a) }}$ & $0.579^{\mathrm{b})}$ & 3055.19 & -36202.37 & -15459.13 \\
\hline \multirow[t]{5}{*}{6} & Constanta & $-0.020^{\mathrm{a})}$ & $-0.551^{c)}$ & $0.702^{\mathrm{c})}$ & 0.314 & -6633.22 & 5098.39 & -22327.32 \\
\hline & F/Wald Test & $17.47^{\mathrm{c})}$ & $3.80^{\mathrm{c})}$ & $10.80^{\mathrm{a})}$ & $32.70^{\mathrm{c})}$ & $135.71^{\mathrm{c})}$ & $28337.51^{\mathrm{c})}$ & $3413.95^{\mathrm{c})}$ \\
\hline & Chow F Test & $2.96^{\mathrm{c})}$ & 0.71 & $17.59^{\mathrm{c})}$ & $20.86^{\mathrm{c})}$ & $2.10^{b)}$ & $21.52^{\mathrm{c})}$ & 0.70 \\
\hline & Haussmann/LM & 0 & 0.00 & 0.33 & 0.75 & 1.20 & $57.93^{\mathrm{c})}$ & 0 \\
\hline & $\mathrm{R}^{2}$ & 0.0778 & 0.0664 & 0.1114 & 0.2464 & 0.7176 & 0.9981 & 0.9846 \\
\hline
\end{tabular}

Source: Result of Data Model Estimation.

Notes:

1) PLS method is the most suitable for this model compare to other method

2) FEM method is the most suitable for this model compare to other method

3) REM method is the most suitable for this model compare to other method

a) Significant at level 10\%; ${ }^{\text {b) }}$ Significant at level 5\%: ${ }^{\text {c) }}$ Significant ant level 1\%

\subsection{Model Estimation: Relationship between Market Structure and Profitability (ROA \& ROE)}

For analysis the effect of market structure to ROA Islamic Banking (IB), the chosen model is a REM model, as the most suitable model in accordance with the test results of Haussmann Test and Breusch and Pagam Lagrangian multiplier test (LM). Individual test result from data panel regression showed that number of Sharia Business Units (SBU) has a significant influence on the performance of ROA, which is shown from the results of the model in Table 2 and 3, the coefficient of SBU has a positive value 0.001 with the value of $P>|z|$ is 0.001 , which means significant at level $1 \%$. It means that an increase of one unit SBU is expected to increase ROA by $0.1 \%$. Meanwhile the other variables (IB, SIZE, HHI and DOWN) did not show any significant effect on ROA BUS, with each value of $\mathrm{P}>|\mathrm{z}|$ is more than 0.10 .

Table 2. Model estimation result-relationship between market structure and Islamic Bank's ROA (REM) ${ }^{1)}$

\begin{tabular}{|c|c|c|c|c|c|}
\hline \multicolumn{3}{|c|}{ Random effect GLS regression } & Number of obs & $=$ & 273 \\
\hline \multicolumn{3}{|c|}{ Group variable $=$ bank } & Number of groups & $=$ & 11 \\
\hline \multirow[t]{4}{*}{ R-sq: } & Within $=$ & 0.0558 & Obs per group: $\min$ & $=$ & 23 \\
\hline & Between $=$ & 0.2980 & Avg & $=$ & 24.8 \\
\hline & Overall $=$ & 0.0778 & Max & $=$ & 25 \\
\hline & & & Wald chi2 (5) & $=$ & 17.47 \\
\hline \multicolumn{3}{|c|}{ Corr $(\mathrm{u} i \mathrm{i}, \mathrm{x})=0$ (assumed) } & Prob $>$ chi 2 & $=$ & 0.0037 \\
\hline
\end{tabular}

Source: Result of Data Model Estimation

${ }^{1)}$ REM method is the most suitable for this model compare to other method 
Table 3. Coefficient result-relationship between market structure and Islamic Bank's ROA (REM) ${ }^{1)}$

\begin{tabular}{lllllll}
\hline ROE & Coefficient & Std. Error & $\mathrm{Z}$ & $\mathrm{P}>|\mathrm{z}|$ & {$[95 \%$ Conf. } & Interval] \\
\hline IB & 0.000 & 0.001 & 0.16 & 0.873 & -0.002 & 0.003 \\
SBU & 0.001 & 0.000 & 3.41 & 0.001 & 0.001 & 0.002 \\
SIZE & $-4.50 \mathrm{e}-10$ & $8.43 \mathrm{e}-10$ & -0.53 & 0.594 & $-2.10 \mathrm{e}-09$ & $1.20 \mathrm{e}-09$ \\
HHI & 0.075 & 0.049 & 1.51 & 0.132 & -0.022 & 0.172 \\
DOWN & -0.005 & 0.012 & -0.38 & 0.704 & -0.029 & 0.020 \\
Constanta & -0.020 & 0.012 & -1.75 & 0.081 & -0.043 & 0.002 \\
sigma_u & 0.017 & & & & \\
sigma_e & 0.049 & \multicolumn{7}{c}{ (fraction of variance due to u_i) } \\
Rho & 0.110 & & & & \\
\hline
\end{tabular}

Source: Result of Data Model Estimation

1) REM method is the most suitable for this model compare to other method

For analysis the effect of market structure to ROE Islamic Banking (IB), the chosen model is a PLS model, as the most suitable model. Individual test result from panel data regression showed that number of Sharia Business Units (SBU) and market concentration (HHI) has a significant influence on the performance of ROE, which is shown from the results of the model in Table 4 and 5, the coefficient of SBU and HHI, has a positive value 0.030 and 1.793 respectively with the value of $\mathrm{P}>|\mathrm{t}|$ is 0.003 for SBU, which significant at level $1 \%$; and the value of $\mathrm{P}>|\mathrm{t}|$ is 0.053 for $\mathrm{HHI}$, which significant at level $10 \%$. It means that the increase of one point of $\mathrm{HHI}$ is expected the ROE will increase by $179 \%$, ceteris paribus. Meanwhile the other variables (IB, SIZE, and DOWN) did not show any significant effect on ROE BUS, with each value of $\mathrm{P}>|\mathrm{t}|$ is more than 0.10 .

Table 4. Model estimation result-relationship between market structure and Islamic Bank's ROE (PLS) ${ }^{1)}$

\begin{tabular}{llllll}
\hline Source & SS & Df & MS & Number of obs & $=273$ \\
\hline Model & 27.7890959 & 5 & 5.55781919 & F $(5,267)$ & $=3.80$ \\
Residual & 390.709272 & 267 & 1.46333061 & Prob $>$ F & $=0.0024$ \\
Total & 418.498368 & 272 & 1.53859694 & R-squared & $=0.0664$ \\
& & & & Adj R-squared $=0.0489$ \\
& & & & Root MSE & $=1.2097$ \\
\hline
\end{tabular}

Source: Result of Data Model Estimation

${ }^{1)}$ PLS method is the most suitable for this model compare to other method

Table 5. Coefficient result-relationship between market structure and Islamic Bank's ROE (PLS) ${ }^{1)}$

\begin{tabular}{lllllll}
\hline ROE & Coefficient & Std. Error & $\mathrm{T}$ & $\mathrm{P}>|\mathrm{t}|$ & {$[95 \%$ Conf. } & Interval $]$ \\
\hline IB & 0.011 & 0.040 & 0.32 & 0.751 & -0.058 & 0.079 \\
SBU & 0.029 & 0.009 & 3.01 & 0.003 & 0.010 & 0.049 \\
SIZE & $-4.17 \mathrm{e}-09$ & $1.91 \mathrm{e}-08$ & -0.22 & 0.827 & $-4.18 \mathrm{e}-08$ & $3.34 \mathrm{e}-08$ \\
HHI & 1.793 & 0.924 & 1.94 & 0.053 & -0.026 & 3.612 \\
DOWN & -0.153 & 0.154 & -1.00 & 0.319 & -0.456 & 0.149 \\
Constanta & -0.551 & 0.185 & -2.98 & 0.003 & -0.914 & -0.187 \\
\hline
\end{tabular}

Source: Result of Data Model Estimation

1) PLS method is the most suitable for this model compare to other method

\subsection{Model Estimation-Relation between Market Structure and Operational Efficiency (OER)}

For analysis the effect of market structure to operational efficiency (OER) of Islamic Banking (IB), the chosen model is a REM model, as the most suitable model in accordance with the test results of Haussmann Test and Breusch and Pagam Lagrangian multiplier test (LM). Individual test result from data panel regression showed 
that number of Sharia Business Units (SBU) and ownership type (DOWN) have significant influence on the performance of OER. From the results of the model in Table 6 and 7, the coefficient of SBU has a negative value- 0.010 with the value of $\mathrm{P}>|\mathrm{z}|$ is 0.033 , which means significant at level $5 \%$. It means that an increase of one unit SBU is expected to reduce the OER by $1 \%$, or more efficient. The coefficient of DOWN has a positive value 0.481 with the value of $\mathrm{P}>|\mathrm{z}|$ is 0.066 , which means significant at level $10 \%$. A positive sign at coefficient DOWN means that the Islamic Bank owned by private company is less efficient compare to Islamic Bank owned by government.

Table 6. Model estimation result-relationship between market structure and Islamic Bank's OER (REM) ${ }^{1)}$

\begin{tabular}{|c|c|c|c|c|c|}
\hline \multicolumn{3}{|c|}{ Random effect GLS regression } & Number of obs & $=$ & 273 \\
\hline \multicolumn{3}{|c|}{ Group variable $=$ bank } & Number of groups & $=$ & 11 \\
\hline \multirow[t]{4}{*}{ R-sq: } & Within $=$ & 0.0293 & Obs per group: $\min$ & $=$ & 23 \\
\hline & Between $=$ & 0.2367 & Avg & $=$ & 24.8 \\
\hline & Overall $=$ & 0.1114 & Max & $=$ & 25 \\
\hline & & & Wald chi2 (5) & $=$ & 10.80 \\
\hline \multicolumn{3}{|c|}{ Corr $(\mathrm{u} i, \mathrm{x})=0$ (assumed) } & Prob $>$ chi 2 & $=$ & 0.0555 \\
\hline
\end{tabular}

Source: Result of Data Model Estimation

${ }^{1)}$ REM method is the most suitable for this model compare to other method

Table 7. Coefficient result-relationship between market structure and Islamic Bank's OER (REM) ${ }^{1)}$

\begin{tabular}{|c|c|c|c|c|c|c|}
\hline ROE & Coefficient & Std. Error & $\mathrm{Z}$ & $\mathrm{P}>|\mathrm{z}|$ & {$[95 \%$ Conf. } & Interval] \\
\hline IB & 0.027 & 0.017 & 1.59 & 0.112 & -0.006 & 0.059 \\
\hline SBU & -0.010 & 0.005 & -2.14 & 0.033 & -0.019 & -0.000 \\
\hline SIZE & $-1.29 \mathrm{e}-08$ & $1.04 \mathrm{e}-08$ & -1.24 & 0.213 & $-3.33 e-08$ & $7.43 \mathrm{e}-09$ \\
\hline HHI & -0.090 & 0.681 & -0.13 & 0.894 & -1.426 & 1.245 \\
\hline DOWN & 0.481 & 0.261 & 1.84 & 0.066 & -0.031 & 0.993 \\
\hline Constanta & 0.702 & 0.221 & 3.17 & 0.002 & 0.267 & 1.137 \\
\hline sigma_u & 0.399 & & & & & \\
\hline sigma_e & 0.571 & & & & & \\
\hline Rho & 0.328 & (fraction o & due to $u \_i$ ) & & & \\
\hline
\end{tabular}

Source: Result of Data Model Estimation

${ }^{1)}$ REM method is the most suitable for this model compare to other method

\subsection{Model Estimation-Relationship between Market Structure and FDR}

For analysis the effect of market structure to Financing to Deposit Ratio (FDR) of Islamic Banking (IB), the chosen model is a REM model, as the most suitable model in accordance with the test results of Haussmann Test and Breusch and Pagam Lagrangian multiplier test (LM). Individual test result from panel data regression showed that number of market concentration (HHI) and ownership type (DOWN) have significant influence on the performance of FDR. From the results of the model in Table 8 and 9, the coefficient of HHI has a positive value 3.015 with the value of $\mathrm{P}>|\mathrm{z}|$ is 0.000 , which means significant at level $1 \%$. It means that the increasing of market concentration will increase the FDR of Islamic Bank. The coefficient of DOWN has a positive value 0.578 with the value of $\mathrm{P}>|\mathrm{z}|$ is 0.032 , which means significant at level $5 \%$. A positive sign at coefficient DOWN means that the Islamic Bank owned by private company has a higher FDR ratio compare to Islamic Bank owned by government. 
Table 8. Model estimation result-relationship between market structure and Islamic Bank's FDR (REM) ${ }^{1)}$

\begin{tabular}{llll}
\hline \multicolumn{2}{l}{ Random effect GLS regression } & Number of obs & $=273$ \\
Group variable $=$ bank & & Number of groups & $=11$ \\
R-sq.: $\quad$ Within $=$ & 0.0970 & Obs per group: min & $=23$ \\
Between $=$ & 0.4391 & Avg & $=24.8$ \\
Overall $=$ & 0.2464 & Max & $=25$ \\
& & Wald chi2 $(5)$ & $=32.70$ \\
Corr (u_i $\mathrm{i}$ ) $=0$ (assumed) & Prob $>$ chi 2 & $=0.0000$ \\
\hline
\end{tabular}

Source: Result of Data Model Estimation

${ }^{1)}$ REM method is the most suitable for this model compare to other method

Table 9. Coefficient result-relationship between market structure and Islamic Bank's FDR (REM) ${ }^{1)}$

\begin{tabular}{lllllll}
\hline ROE & Coefficient & Std. Error & $\mathrm{Z}$ & $\mathrm{P}>|\mathrm{z}|$ & {$[95 \%$ Conf. } & Interval] \\
\hline IB & 0.011 & 0.014 & 0.80 & 0.424 & -0.016 & 0.039 \\
SBU & -0.003 & 0.004 & -0.84 & 0.398 & -0.011 & 0.004 \\
SIZE & $5.53 \mathrm{e}-09$ & $8.95 \mathrm{e}-09$ & 0.62 & 0.537 & $-1.20 \mathrm{e}-08$ & $2.31 \mathrm{e}-08$ \\
HHI & 3.015 & 0.599 & 5.03 & 0.000 & 1.839 & 4.190 \\
DOWN & 0.578 & 0.269 & 2.15 & 0.032 & 0.050 & 1.107 \\
Constanta & 0.314 & 0.224 & 1.40 & 0.162 & -0.126 & 0.754 \\
sigma_u & 0.419 & & & & & \\
sigma_e & 0.488 & & & & & \\
Rho & 0.425 & (fraction of variance due to u_i) & & & \\
\hline
\end{tabular}

Source: Result of Data Model Estimation

${ }^{1)}$ REM method is the most suitable for this model compare to other method

\section{Discussion}

\subsection{Impact of Market Structure to Profitability (ROA \& ROE)}

From Table 1 we can see that number of Islamic Bank did not show any significant impact to profitability of Islamic Bank both ROA and ROE; however the increasing number of Islamic Bank may reduce the average profit of the IB, as it is shown at Table 1, with the value of -1898.08 and significant level at $5 \%$. Meanwhile, number of Sharia Business Unit has a positive impact to profitability of Islamic Bank, both ROA and ROE. This condition shows that the additional of SBU which is located at conventional bank holding location, can increase the awareness of conventional bank customer regarding the sharia product, and it lead them to open account at SBU or Islamic Bank, especially for the financing (Table 1, shows the relationship between SBU and financing (FIN) is positive and significant at level 1\%).

Size and the market concentration of the Islamic Bank did not show any significant influence directly to the ROA; however it can increase the average number of profit for the Islamic Bank, so that the increasing of size and market concentration will increase the average profit. Table 10 shows the total asset and HHI of Islamic banking in Indonesia for period 2010-2011. By the end of 2011 the market share of Islamic banking was dominated by two banks namely Bank Mandiri Sharia (41\%) and Bank Muamalat Indonesia (27\%), with HHI values respectively 1.744 and 776 . The HHI score of 2,705 or more than 1800 shows that the Islamic banking industry is highly concentrated in a few companies, in this case are concentrated in Bank Mandiri Sharia and Bank Muamalat Indonesia. 
Table 10. Market share of Indonesian Islamic Banks 2010-2011

\begin{tabular}{|c|c|c|c|c|c|c|c|c|c|c|c|c|}
\hline \multirow{2}{*}{ Bank Name } & \multirow{2}{*}{ Est. } & \multicolumn{3}{|c|}{ Total Assets (IDR Trillion) } & \multicolumn{2}{|c|}{$\begin{array}{l}\text { Market Share } \\
(\%)\end{array}$} & \multicolumn{2}{|l|}{ HHI } & \multicolumn{2}{|c|}{ ROA (\%) } & \multicolumn{2}{|c|}{ ROE (\%) } \\
\hline & & 2010 & 2011 & Growth $\%$ & 2010 & 2011 & 2010 & 2011 & 2010 & 2011 & 2010 & 2011 \\
\hline Muamalat & 1992 & 21,442 & 32,479 & 51.5 & 27.1 & 27.8 & 736.3 & 776.8 & 1.3 & 1.5 & 17.7 & 20.7 \\
\hline Mandiri Sharia & 1999 & 32,481 & 48,671 & 49.8 & 41.1 & 41.7 & $1,689.7$ & $1,744.4$ & 2.2 & 1.9 & 63.5 & 64.8 \\
\hline Mega Sharia & 2004 & 4,637 & 5,565 & 20.0 & 5.8 & 4.7 & 34.4 & 22.8 & 1.9 & 1.5 & 26.8 & 16.8 \\
\hline BRI Sharia & 2008 & 6,856 & 11,200 & 63.4 & 8.6 & 9.6 & 75.2 & 92.3 & 0.3 & 0.2 & 1.3 & 1.2 \\
\hline Bukopin Sharia & 2008 & 2,193 & 2,730 & 24.4 & 2.7 & 2.3 & 7.7 & 5.4 & 0.7 & 0.5 & 9.6 & 6.2 \\
\hline Panin Sharia & 2009 & 458 & 1,016 & 121.7 & 0.5 & 0.8 & 0.3 & 0.7 & -2.5 & 1.7 & -4.7 & 2.8 \\
\hline BCA Sharia & 2010 & 874 & 1,217 & 39.2 & 1.1 & 1.0 & 1.2 & 1.1 & 0.7 & 0.9 & 1.2 & 2.3 \\
\hline BNI Sharia & 2010 & 6,394 & 8,466 & 32.4 & 8.1 & 7.2 & 65.5 & 52.7 & 0.6 & 1.2 & 3.6 & 6.6 \\
\hline BJB Sharia & 2010 & 1,930 & 2,849 & 47.6 & 2.4 & 2.4 & 5.9 & 5.9 & 0.7 & 1.2 & 1.6 & 3.6 \\
\hline Maybank Sharia & 2010 & 1,410 & 1,692 & 20.0 & 1.7 & 1.4 & 3.1 & 2.1 & 4.4 & 3.5 & 5.4 & 4.9 \\
\hline Victoria Sharia & 2010 & 336 & 642 & 90.7 & 0.4 & 0.5 & 0.2 & 0.3 & 1.1 & 6. & 2.4 & 18.7 \\
\hline Total & & 79,018 & 116,533 & 47.5 & 100 & 100 & & & & & & \\
\hline CR4 Ratio & & 0.85 & 0.87 & & & & & & & & & \\
\hline
\end{tabular}

Source: Data Analysis from Indonesian Central Bank Statistics 2011.

Table 10 shows that from 2010 to 2011 there were 6 Islamic Banks that enter the market, which influences the market share and HHI of individual Islamic banking in Indonesia. Most of the banks that increase their assets increase their HHI as well as their ROE, as Bank Mandiri Sharia, Bank Muamalat, BJB Sharia, and Panin Sharia. Even though there are several small banks that increase their assets but their HHI decrease as well as their profitability (ROA and ROE) such as Bukopin Sharia, MayBank Sharia, and Mega Sharia. This condition shows that the profitability of Islamic Bank in Indonesia is not only influenced by market concentration, but also influenced by other factors, however for some extend the HHI can influence the ROE of Islamic Bank in Indonesia. From Table 1 and Table 10, we can see that the ownership of Islamic bank, whether government or private, did not have significant influence to the profitability. However the government Islamic Bank tends to have a higher growth in assets compare to private Islamic bank, so that their increase their market shares.

The result that shows the market concentration has positive relationship with the profitability (ROE) is consistent with several previous studies that have examined the structure of the market, in their evaluation of the performance of the bank (Evanoff \& Fortier 1988; Molyneux \& Thornton, 1992; Molyneux \& Forbes, 1995; Chirwa, 2003; Batti \& Hussein, 2010). Contrary to the research conducted by Flamini et al. (2009) in Commercial Bank Profitability in Sub-Saharan Africa, that showed that the market concentration had no direct effect on bank profitability estimation.

\subsection{Impact of Market Structure to Operational Efficiency (OER)}

The result of this research shows that number of Sharia business unit and type of ownership influence the operational efficiency of Islamic bank. The presence of Sharia business unit at conventional bank holding location will increase the penetration of Islamic banking product and services thru the captive market of conventional bank customer, and it will minimize the investment cost required for opening a new branch.

Based on the research of Rivai et al. (2007) showed that consumers and prospective consumers have rational considerations in choosing a bank including economic motives to make his choice. Around $51.4 \%$ from 214 respondents of conventional bank customers mentioned that they choose Islamic Bank because of the interest, instead of the concept of religion. They also still choose various products offered by conventional banks. From the study also showed that $61 \%$ of respondents are considering moving to the Islamic banks. The respondents who expressed that they did not interest in moving from conventional banks to Islamic banks, stated that the main reasons were (a) the information of Islamic Banking is not clear, (b) does not know about Islamic banking products, (c) limited branch network of Islamic banks, and (d) currently they don't require the services of Islamic banking.

Thus the existence of SBU on Conventional Banks can be an impetus for conventional bank customers who are interested in moving into Islamic banks or wanting to gain more benefits of the product and service Islamic bank. It can also improve the efficiency of the Islamic Bank, because indirect costs of the promotion of Islamic 
banking services carried out by Islamic business units are located in a conventional bank location. From the ownership type, the Islamic bank owned by government is more efficient compare to private Islamic bank. One of the reasons is that many of government Islamic bank outlets are located at conventional bank holding branches. So that, the more the conventional bank holding shares its infrastructure with its subsidiary bank, the more efficient the cost. Associated with economies of scale, that the increasing benefits to the economies of scale is possible by the low transaction costs (fixed costs of capital invested, the branches, the ATM system, etc.), when joint production for different financial services, can be reduced by using the same cost factors, and if the provision of different services to the customers can reduce the cost of collecting information.

This result support the previous studies related to economy of scale, that if an industry is subject to economies of scale, the larger institutions will be efficient and can provide services at a lower cost level, which is cheaper and efficient than smaller banks. As a result of market share gain, the bigger bank can increase revenue and profits. (Athanasoglou et al., 2006; Neuberger, 2007; Flamini et al., 2009).

\subsection{Impact of Market Structure to the Performance of Liquidity (FDR)}

The result of this research shows that number of Islamic Bank, size of company and number Sharia business unit did have any significant influence to the performance of liquidity (FDR), however the increasing of Islamic bank can reduce the average financing of the Islamic bank, meanwhile the increasing of size, market concentration and number of SBU can increase the financing of Islamic bank. The result showed that FDR level of private owned Islamic bank was higher than the FDR level of government-owned Islamic Bank. Several private Islamic banks have more than $100 \%$ of FDR level, due to the total of deposit of private Islamic bank is much lower than the deposit of government owned Islamic. The high level of FDR can lead to liquidity risk, if the banks do not immediately improve their third-party funds.

\section{Conclusions}

From the empirical findings of this study, related to the impact of market structure to the performance of the Islamic Bank in Indonesia, can be concluded as follows:

1) The market structure of the Islamic banking in Indonesia is an oligopolistic competition which is concentrated in two large banks Bank Mandiri Sharia and Bank Muamalat, with HHI scores are 1.744 and 776 respectively. In line with the increasing of their HHI, both banks also increased their profitability. Data model estimation result also indicates that market concentration influenced the ROE of Islamic Bank in Indonesia.

2) The new entrance to the Islamic banking market in Indonesia (such as additional number of new Islamic Bank and Sharia Business Unit) increased the competition of Islamic Banks in achieving their funding and financing market share. However the additional of Sharia Business Unit, gave a positive influence on the performance of ROA and ROE Islamic Bank. This condition indicates that the presence of Sharia Business Unit outlet as well as Islamic Bank outlet at bank holding location, can improve the efficiency of the Islamic Bank, because it can reduce the overhead and the investment cost of Islamic Banking services.

3) The opening of Sharia business unit at conventional banking or office channeling may be one of the best policy options, since it can increase the Islamic banking market share, increase profitability and also more efficient compared to opening a new office branch. However, to minimize the potential bankruptcy of the bank because of the high competition, regulators also need to further examine the factors that influence in shifting the structure of the Islamic banking business, thus becoming efficient financial institutions and may provide greater benefits.

\section{References}

Ajlouni, M. (2010). The Main Features of the Structure-Conduct-Performance (SCP) Literature in Banking during the period 1960s-1980s. International Journal of Economic Perspective, 4(3), 509-523. Retrieved from http://search.proquest.com/docview/846923961_accountid=32819

Athanasoglou, P. P., Delis, M., \& Staikouras, C. (2006). Determinants of Banking Profitability in the South Eastern European Region. Bank of Greece Working Paper, 6(47). Retrieved from http://www.bankofgreece.gr/BogEkdoseis/Paper200647.pdf

Bain, J. S. (1950). Workable competition in oligopoly: Theoretical Considerations and Some Empirical Evidence. The American Economic Review, 40(2), 35-47. Retrieved from http://www.jstor.org/stable/1818021

Bain, J. S. (1951). The Relation of Profit Rate to Industry Concentration: American Manufacturing, 1936-1940. Quarterly Journal of Economics, 65(3), pp. 293-324. http://dx.doi.org/10.2307/1882217

Baltagi, B. (2005). Econometric Analysis of Panel Data (3rd ed.). Chichester: John Wiley \& Sons Ltd. 
Bhatti, G. A., \& Hussain. (2010). Evidence on Structure Conduct Performance Hypothesis in Pakistani Commercial Banks. International Journal of Islamic Banking and Management, 5(9), 174-187. Retrieved from http://www.ccsenet.org/journal/index.php/ijbm/article/view/7325

Bourke, P. (1989). Concentration and Other Determinants of Bank Profitability in Europe, North America and Australia. Journal of Banking and Finance, 13, 65-79. http://dx.doi.org/10.1016/0378-4266(89)90020-4

Boyd, J. H., \& Runkle, D. E. (1993). Size and Performance of Banking Firms. Testing the Predictions of Theory. Journal of Monetary Economics, 31, 47-67. http://dx.doi.org/10.1016/0304-3932(93)90016-9

Chirwa, E. W. (2003). Determinants of commercial banks' profitability in Malawi: A cointegration approach. Applied Financial Economics, 13(8), 565-571. http://dx.doi.org/10.1080/0960310022000020933

Demsetz, H. (1973). Industry Structure, Market Rivalry, and Public Policy. Journal of Law and Economics, 16, 1-9. Retrieved from http://EconPapers.repec.org/RePEc:ucp:jlawec:v:16:y:1973:i:1:p:1-9; http://dx.doi.org/10.1086/466752

Evanoff, D. D., \& Fortier, D. L. (1988). Re-evaluation of the Structure conduct Performance Paradigm in Banking. Journal of Financial Services Research, 1(3), 277-294. http://dx.doi.org/10.1007/BF00114854

Flamini, V., McDonald, C., \& Schumacher, L. (2009). The Determinants of Commercial Bank Profitability in Sub-Saharan Africa. IMF Working Paper, 9(15), 13-14. Retrieved from http://ssrn.com/abstract=1356442; http://dx.doi.org/10.5089/9781451871623.001

Gilbert, R. A. (1984). Bank Market Structure and Competition: A Survey. Journal of Money, Credit and Banking, 16(4), 617-645. http://dx.doi.org/10.2307/1992096

Goddard, J., Molyneux, P., \& Wilson, J. O. S. (2004). Dynamics of Growth and Profitability in Banking. Journal of Money, Credit and Banking, 36, 1069-1090. Retreived from http://www.jstor.org/stable/3839101; http://dx.doi.org/10.1353/mcb.2005.0015

Hadad, M. D., Sugiarto, A., Purwanti, W., Hermanto, J., \& Arianto, B. (2003). Kajian Mengenai Struktur Kepemilikan Bank di Indonesia. Bank Indonesia. Jakarta. Retrieved from http://www.bi.go.id/id/publikasi/perbankan-dan-stabilitas/riset/Pages/Kajian Mengenai Struktur Kepemilikan Bank.aspx

Hariandy, H., \& Haruman, T. (2011). Banking: According to Islamic Sharia Concepts and Its Performance in Indonesia. International Review of Islamic Banking Research Papers, 7(1), 60-76. Retrieved from http://www.bizresearchpapers.com/5.\%20Hariandy\%20Hasbi-FINAL.pdf

Heggestad, A. A. (1977). Market Structure, Risk and Profitability in Commercial Banking. Journal of Finance, 32(4), 1207-1216. http://dx.doi.org/10.1111/j.1540-6261.1977.tb03321.x

Heggestad, A. A., \& Mingo, J. J. (1977). The Competitive Condition of US Banking Markets and the Impact of $\begin{array}{lllll}\text { Structural Reform. } & \text { Journal }\end{array}$ http://dx.doi.org/10.1111/j.1540-6261.1977.tb01978.x

Ismail, A. G. (2010). Money, Islamic Bank and the Real Economy. Cecgage Learning Asia Pte. Ltd. Malaysia.

Lewis, M. K., \& Davis, K. T. (1987). Domestic and International Banking. England, Philip Allan.

McLeay, S., Molyneux, P., \& Institute of European Finance. (1989). Bank profitability and structure in France, the United Kingdom, West Germany and Japan: Some preliminary findings. Bangor: University College of North Wales. Institute of European finance, (12). Retrieved from http://hdl.handle.net/10068/497876

Molyneux, P. L., Williams, D. M., \& Thornton, J. (1994). Market Structure and Performance in Spanish Banking. Journal of Banking and Finance, 18(3), 433-443. Retrieved from http://www.econbiz.de/Record/market-structure-and-performance-in-spanish-banking-lloyd-williams-micha el/10001168010; http://dx.doi.org/10.1016/0378-4266(94)90002-7

Molyneux, P., \& Fobers, W. (1995). Market Structure and Performance in European Banking. Applied Economics, 27(2), 155-159. http://dx.doi.org/10.1080/00036849500000018

Molyneux, P., \& Thornton, J. (1992). Determinants of European Bank Profitability: A Note. Journal of Banking and Finance, 16, 1173-1178. http://dx.doi.org/10.1016/0378-4266(92)90065-8

Naceur, S. B. (2003). The Determinant of the Tunisians Banking Industry Profitability; Panel Evidence. Tunis. Retrieved from http://www.mafhoum.com/press6/174E11.pdf 
Neuberger, D. (1997). Structure, Conduct and Performance in Banking Market. Universität Rostock. Wirtschafts und Sozialwissenschaftliche Fakultät Institut für Volkswirtschaftslehre. Thünen Series of Applied Economic Theory, 12. Retrieved from http://hdl.handle.net/10419/78254

Panagiotou, G. (2006). The Impact of Managerial Cognitions on The Structure-Conduct-Performance (SCP) Paradigm. Managerial Decision, 44(3), 423-441. http://dx.doi.org/10.1108/00251740610656296

Rivai, V., Veithzal, A. P., \& Idroes, F. N. (2007). Bank and Financial Institution Management; Conventional and Sharia System. PT Raja Grafindo. Jakarta.

Samad, A., \& Hassan, M. K. (2000). The Performance of Malaysian Islamic Bank During 1984-1997: An Exploratory Study. International Journal of Islamic Financial Services, 1(3). Retrieved from http://www.ukm.my/hairun/kertas\%20kerja\%20assignment/malaysian\%20islamic\%20banks.pdf

Short, B. K. (1979). The relation between commercial bank profit rates and banking concentration in Canada, Western Europe and Japan. Journal of Banking and Finance, 3, 209-219. Retrieved from http://www.lib.ctgu.edu.cn:8080/wxcd/qw/153.pdf; http://dx.doi.org/10.1016/0378-4266(79)90016-5

Smirlock, M. (1985). Evidence on the Non Relationship Between Concentration and Profitability in Banking. Journal of Money, Credit and Banking, XVII(1). http://dx.doi.org/10.2307/1992507

Smirlock, M., \& Brown, D. (1986). Collusion, Efficiency and Pricing Behavior: Evidence From the Banking Industry. Economic Inquiry, XXIV(1), 85-96. http://dx.doi.org/10.1111/j.1465-7295.1986.tb01798.x

\section{Copyrights}

Copyright for this article is retained by the author(s), with first publication rights granted to the journal.

This is an open-access article distributed under the terms and conditions of the Creative Commons Attribution license (http://creativecommons.org/licenses/by/3.0/). 